\title{
THE FINANCIAL AND ECONOMIC ASPECTS OF TRANSPORT INFRASTRUCTURE DEVELOPMENT IN LATVIA
}

\author{
Irina Kuzmina-Merlino ${ }^{1}$, Oksana Skorobogatova ${ }^{2}$, \\ Niels Schmidtke ${ }^{3}$, Fabian Behrendt ${ }^{4}$ \\ ${ }^{1,2}$ Transport and Telecommunication Institute \\ Lomonosova street 1, Riga, LV-1019, Latvia \\ ${ }^{I}$ Ph.:+371-67109389.E-mail: Kuzmina.I@tsi.lv \\ ${ }^{2}$ Ph.: +371-67100558. E-mail: Skorobogatova.O@tsi.lv \\ ${ }^{3}$ Fraunhofer Institute for Factory Operation and Automation IFF \\ Sandtorstraße 22, 39106 Magdeburg, Germany \\ Ph.: +49-3914090 568. E-mail: niels.schmidtke@iff.fraunhofer.de \\ ${ }^{4}$ SRH The Mobile University, Lange Str. 19, 88499 Riedlingen, Germany \\ Ph.: +49-391 4090 411. E-mail: fabian.behrendt@iff.fraunhofer.de
}

\begin{abstract}
This paper is devoted to topical issues in the development of transport infrastructure as a key component of the transport system of Latvia. The level of development of transport infrastructure is measured by specific economic indicators, which in their turn depend on the volume and efficiency of acquisition of sources of funding. The paper sheds light on the economic indicators of the development of the transport infrastructure in Latvia and issues of funding of this sector. The data contained in this paper reveals the size and directions of public investment in the transport infrastructure development. The paper focuses on the necessity to create the effective investment mechanism for financing the transport infrastructure of Latvia as a useful instrument in making investment decisions. Based on the theory of decision making the authors developed Investment Decision-Making Concept, which can be used when selecting investment projects in the field of transport infrastructure and their evaluation. This paper is based on the literature review of previously published papers of these authors. The authors refine their conceptual approach for developing an invest ment decision making mechanism, proposed in earlier papers, and offer recommendations aimed at policy-makers, professionals, academics and those with a broad interest in the field.
\end{abstract}

Keywords: Transport Infrastructure, Performance, Investment Decision-Making

\section{Introduction}

Transport is an important part of the world economy, since the complex development of any state is impossible without a transport system. The priorities for the development of the transport sector are determined by the decisions of the Latvian government; thus, the emphasis is placed on international cooperation and position of Latvia as a transit corridor between West and East. Investment and its effective use are required to provide the long-term development of this sector. The assimilation of investment in the transport sector, above all, in the transport infrastructure brings real economic benefits in the form of gross national product growth and improvement of the quality of life of people as evidenced by official statistics. High quality transport infrastructure associated with high level of economic development. When transport systems are efficient, they provide economic and social opportunities and benefits that result in positive multipliers effects such as better accessibility to markets, employment and additional investments (Rodrigue et al., 2017). The economic effects of different types of transport infrastructure investments using different evaluation models was studied by Italian researchers such as Claudio Ferrari and others (Ferrary et al., 2018).

In the context of significantly limited funds of national budget of the Republic of Latvia and the European Union (EU), EU budget, there emerges a serious problem of choosing the way and format of financing the development of transport infrastructure. International experts forecast a significant increase in the need for investment in transport infrastructure in the future. The total amount of infrastructure investment required to sustain economic growth in the countries of the Organization in Economic Cooperation and Development (OECD) to 2030, is estimated to be above 50 trillion in United States Dollars (USD) (Panayiotou and Medda, 2014).

The object of research in this paper is transport infrastructure. The subject of the research is economic and financial aspects of transport infrastructure development. 
The economic aspects of development of transport infrastructure are defined here as indicators measuring the impact of transport infrastructure on the economy of the country. The financial aspects are linked to finance issues related to the development of transport infrastructure and the effectiveness of investments. This paper argues that economic and financial aspects of development of transport infrastructure are interconnected because the enhancement of the investment policies creates a favourable effect on the economic growth of the country and improves the quality of life of the population.

The aim of this paper is to show the needs to increase financial support to development of transport infrastructure and to better connect the investment policy to the improvement of its economic performance.

The following tasks have been formulated to achieve the research aim:

1) Prove the strategic priority of the development of transport infrastructure for the economy of Latvia;

2) Determine if transport sectors are attractive for investors;

3) Review of how the development of transport infrastructure is financed;

4) Determine how to enhance financing of the development of transport infrastructure and make it more effective for the economy of the country.

\section{Research Methods}

The choice of methodology used in this study has been determined by the logic of solving the research issues and by the necessity to achieve the research aim. In this study, the authors used analytical and logical-structural approaches, statistical and graphical methods of data processing and presentation, as well as the method of comparative economic analysis.

To receive answers to the research questions, the authors of the present paper have applied the appropriate methods of scientific research.

The accessible economic information, research findings, statistical data published by the state institutions of the Republic of Latvia, data published by OECD and World Bank are used in the paper in order to define the role of the transport infrastructure in the development of transport economy. Analysing and compiling the collected information revealed the basic tendency in the development of transport sector and confirmed the priority of its development for the Latvian economy.

Case study method was used to demonstrate an example of successful investment project and its impact on the quality and efficiency of railway passenger services.

Analysis of official statistical information on the plans and results of financing the projects for the development of transport infrastructure provides the conclusions about the sources of project funding, size of invested funds and directions of investment. Also, it gives an idea of further public financing for the development of transport sector within the context of national development strategy.

For improvement of transport infrastructure investment process the authors developed investment decision-making concept based on cost-benefit analysis and multi-criteria analysis. The result (costbenefit ratio $>$ then 1) describes a meaningful project from macroeconomic perspective. The composite modelling assessment (COSIMA) takes into account not macroeconomic factors only, but microeconomic factors also. This model helps to fix priority of financial allocation and to assure its economic effectiveness and can be considered as an effective tool for the evaluation of alternative investment projects.

The results of this study confirmed the relevance of the examined research subject; further studies may be aimed at the impact analysis of investment in the development of transport infrastructure, as well as at assessing the efficiency of the public funding assimilation.

\section{Transport Infrastructure Development Performance}

Latvia is located on the eastern coast of the Baltic Sea. One of the priorities of the development of Latvia is a development of safe, sustainable and environment-friendly transport system, in particular multimodal transport. The main objective of sustainable development of transport in Latvia is an integration of the transport infrastructure with the trans-European system. Special attention is directed on the development of a long-coast shipping and combined transport. The main elements of the Latvian transport infrastructure comprise:

- Riga international airport;

- Free port of Riga and other ports in Ventspils and in Liepaja;

- Railway transport; 
- 33 international coach terminals;

- City public transport;

- Dense and functional networks of roads which are connected with the European Union and Commonwealth of Independent States (CIS) networks and Latvian ports;

Special high-capacity railway corridor that connects Latvian ports with Russia and the Far East.

Latvia recognizes the development of an effective, secure, multi-modal, balanced, environmentally friendly and competitive transport system to be a priority (LIAA, 2018). The main goal for the sustainable development of Latvia transport system is to integrate fully Latvia transport infrastructure with the TransEuropean multi-modal transport system. In developing the transport and energy infrastructure of the European Union, the conditions that are viewed as essential are the following: the effective use of the transport and energy network, planning the development from an economic point of view, considering established goods and passenger transport corridors, the development potential of economic relations between the European Union and neighbouring countries.

The transit sector is one of the strongest industrial sectors in Latvia. Nearly $90 \%$ of turnover in Latvian ports, more than $80 \%$ of rail cargo, and the major proportion of oil and oil products transported via trunk pipeline systems is transit. More than $8 \%$ of Latvia's employees are engaged in the transportation and servicing of transit cargo. The importance of the transport, transit and storage sector in terms of Growth Domestic Product (GDP) contribution is substantial at around 8\% in 2014 (LIAA, 2015) and $9.5 \%$ in 2015 (LIAA, 2016). Competitive labour and favourable government policies aimed at improving transport infrastructure, promoting railway freight, simplifying customs procedures with Russia and promoting the use of information and communication technologies (ICT) and new technologies further contribute to the potential of the sector.

What are the plans of government of Latvia in this connection? Transport issues have been discussed in all national-level policy planning documents, the most important of which "Sustainable Development Strategy of Latvia until 2030", where is written that one of the main objective is "to promote the development of Latvia as transit state, as well as will ensure more efficient co-operation platform in international scale" (Saeima, 2010). Table 1 shows the priority plans of development of transport infrastructure.

Table 1. Strategy of Sustainable Development: special development perspectives (Saeima, 2010)

\begin{tabular}{|c|c|c|}
\hline & From $(2010)$ & 2030 \\
\hline Number of inhabitants (million) & 2,26 & $>2,02$ \\
\hline Gini coefficient & 38 & $<30$ \\
\hline Motorways with black asphalt from regional state motorways $(\%)$ & 75 & 100 \\
\hline Number of foreign tourists who are staying for 4 days and more (million, per year) & 0,4 & $>1,5$ \\
\hline Freight turnover in ports of Latvia (million of tons per year) & 63,6 & $>130$ \\
\hline $\begin{array}{l}\text { Passenger circulation in public transport } \\
\text { (million of passenger kilometres of scheduled traffic buses per year) }\end{array}$ & 2487 & 2850 \\
\hline Number of the serviced air traffic passengers in the airport — Rigall (million, per year) & 3,69 & $>10$ \\
\hline Passenger circulation in railway transport (million passenger kilometres per year) & 951 & 1150 \\
\hline Number of the services passengers in the Riga Port (thousand, per year) & 503,6 & $>1500$ \\
\hline
\end{tabular}

The tasks of transport infrastructure development are considered in the context of solving economic and social problems and environmental problems; it allows achieving the long-term economic development of Latvia. Statistical data demonstrate the active development of the transport industry, which government documents declare as a priority direction of development of the economy of Latvia. Therefore, it can be argued that the relevance of the development of transport infrastructure in Latvia is increasing. In this regard, scientific interest in the object of study is enhancing (Skorobogatova and Kuzmina-Merlino, 2017).

Transport infrastructure is one of the most important parts of the infrastructure of the economy. Transport activity, a key component of economic development and human welfare, is increasing around the world as economies are growing. Transportation is a reflection of economic activity. A good transport network is important in sustaining economic success in modern economies. According to American 
Professor Ishaq Nadiri (1997), who is considered as a pioneer in the study of this question, infrastructure investment "had dramatic impact on the rate of economic growth".

However, the analysis of economic literature shows that the relationship between transport and the economy is discussed in both academic and non-academic circles. According to the authors of the paper, undoubtedly there is a mutual connection between the quality of transport infrastructure and the macroeconomic performance of the country. Well-developed transport infrastructure gives certain benefits through certain macroeconomic drivers of productivity. These drivers of productivity are improvement of business activity, innovations and investments, labour market, competition, domestic and international trade globally mobile activity, regional economic development, wellbeing of population, environment safety and health. In many developed countries, transportation accounts between $6 \%$ and $12 \%$ of the GDP (Rodrigue et al., 2017). The interaction between transport infrastructure and economic growth in general can be presented as a simple scheme (Fig. 1):

Transport infrastructure development $\longleftrightarrow \begin{aligned} & \text { Increased number and improved } \\ & \text { quality of goods and services } \\ & \text { delivered to the customers }\end{aligned} \quad \Longrightarrow$ Growth of GDP/Capita

Figure 1. Transport infrastructure and economic growth (Skorobogatova and Kuzmina-Merlino, 2017)

Well-developed transport infrastructure has a direct impact on the quality and cost of logistics services because infrastructure allows reducing the time and cost of transportation, it decreases risk and improves quality of logistics services by improving the comfort, safety and security.

The debate about transport and the economy takes place against the background of significant trends in both. Figure 2 seeks to give some indication of how the Latvian economy and the demand for the passenger and freight transport have changed over time. Figure 2 shows that the passenger traffic does not present any significant change during the period from 2006 till 2016, it is evident that passenger transport "feel comfortable", regardless of changes in the level of Gross Domestic Product (GDP). At the same time development trends of freight and transport does not always correspond to the line changes of GDP. It can be concluded that the role of freight transport as a contribution to GDP has varied over the analysed period.

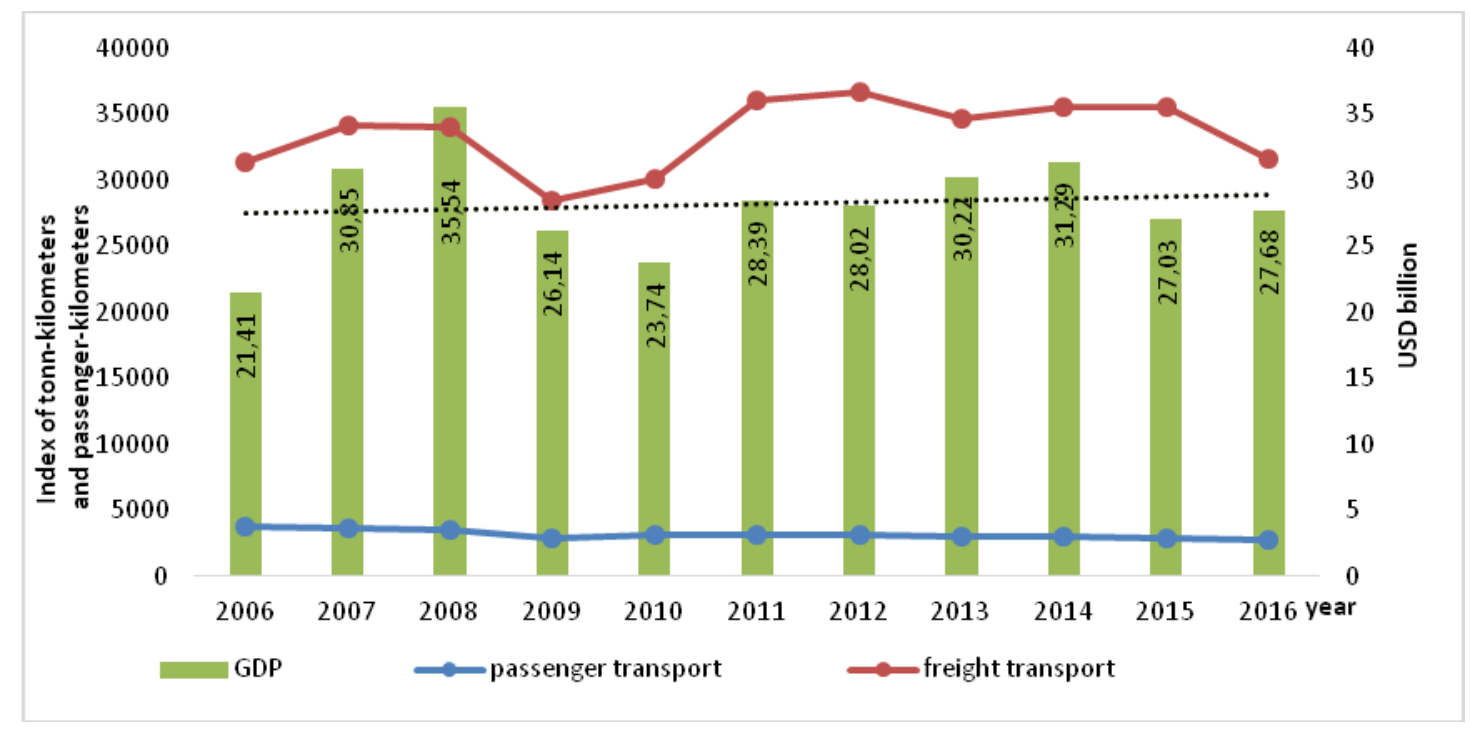

Figure 2. Transport trends against GDP: Latvia 2006-2016 (developed using methodology of SACTRA Source: Central Statistical Bureau of Latvia)

Therefore, from theoretical point of view, it is possible to conclude that growth in transport at infrastructure corresponds to growth in the economy. However, the relationships between transport infrastructure and the economy are very complex; thus, it is very difficult to measure their interrelation.

Infrastructure today should be regarded as one of the key factors determining the competitiveness of the economy and, as a consequence, its growth. Infrastructure projects have a unique ability to create new jobs in the short term and increase productivity in the long term. 


\section{Financing of Development of Transport Infrastructure in Latvia}

Due to its economic nature, transport infrastructure represents a critical component in economic development of any country at all levels of income. It supports a country's economic growth and the quality of life of the general population. International experts forecast a significant increase in the need for investment in transport infrastructure in the future.

According to the research by Oxford Economics transport infrastructure investment is projected to increase at an average annual rate of about 5\% worldwide over the period of 2014 to 2025 . Western Europe's share of global transport infrastructure spending is forecast to change from $11 \%$ in 2014 to $10 \%$ in 2025. For the most of Central Eastern European countries, transport infrastructure investment is expected to increase an average of nearly 10\% annularly from 2014 to 2025 (Oxford Economics, 2015). It is estimated that USD 350-770 billion in transport is needed annually by developing countries between 2015 and 2030 (Zhan, 2015).

Different approaches are implemented to evaluate the results of development of transport infrastructure in international aspect. The most famous are as follows:

- Assessment of transport infrastructure on the basis of the calculation of the Global Competitiveness Index (GCI), by using the World Economic Forum.

- Evaluation of the supply chain service delivery based on the evaluation of Logistics Performance Index (LPI), which was developed by the World Bank in 2007.

- The Doing Business project, launched in 2002, looks at domestic small and medium-size companies and measures the regulations applying to them through their life cycle.

The Global Competitiveness Index (GCI) measures the level of competitiveness of an economy, which is defined as the set of institutions, policies, and factors that determine the level of productivity of an economy. Measurement of the level of transport infrastructure is one of the parts of total evaluation of the GCI. The Logistics Performance Index (LPI) analyses differences between countries in terms of customs procedures, logistics costs and the quality of the infrastructure for overland and maritime transport. LPI is the weighted average of the country scores on the six key dimensions. LPI values range from 1 (worst) to 5 (best) and show that building the capacity to connect firms, suppliers and consumers, is a key in a context where predictability and reliability are becoming as important as costs in sourcing decisions. A value of less than 3.0 usually reflects an array of problems within a nation's freight distribution system causing undue delays and additional costs.

By gathering and analysing comprehensive quantitative data to compare business regulation environments across economies and over time, Doing Business encourages economies to compete towards more efficient regulation; offers measurable benchmarks for reform; and serves as a resource for academics, journalists, private sector researchers and others interested in the business climate of each economy. The first Doing Business report, published in 2003, covered 5 indicator sets and 133 economies. 2018 year's report covers 11 indicator sets and 190 economies. The initial goal remains: to provide an objective basis for understanding and improving the regulatory environment for business around the world (The World Bank, 2018).

According to the Global Innovation Index (GII) 2016 Report, Latvia is ranked $35^{\text {th }}$ in terms Logistic performance index with score 62.9 and value 3.4 (for comparison: Germany is ranked the first with score 100 and index value equal to 4.1) (The Global Innovation Index, 2017). These factors indicate the investment attractiveness of Latvia for capital expenditure to the transport industry, designated as a priority sector in terms of strategic development of the country.

Among the main shortcomings of the current functioning of Latvian transport, the factor that is especially worth mentioning is the low technical level and the unsatisfactory condition of its production and technical base. The lack of public funding for the transport industry as a whole and infrastructure in particular can be considered as the reason for this. However, as the international practice shows, only the state at the expense of its own resources is not able to implement the entire complex of tasks for the development of transport infrastructure.

EU funding is one of the main sources of investment in the Latvian economy, reducing the negative effects of the economic downturn during the crisis and stimulating economic stabilization and economic growth recovery. Figure 3 shows distribution of EUR 4,5 billion EU funds investment in 2007 $-2013$. 


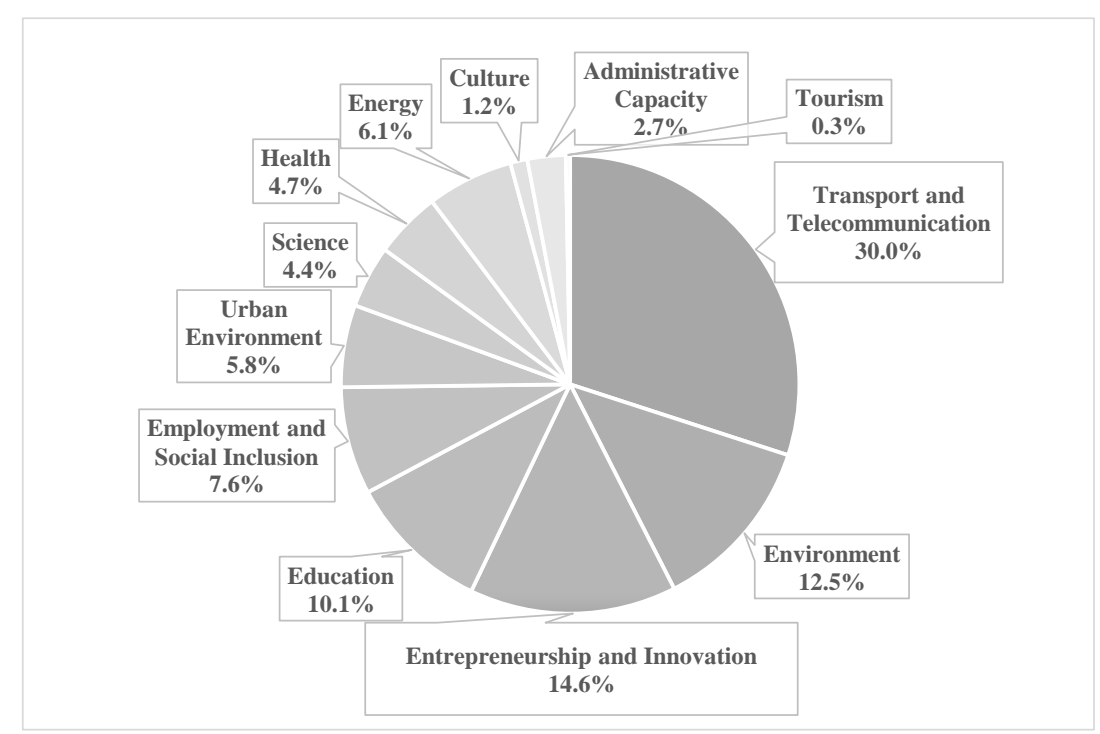

Figure 3. Distribution of EU funds by industry, \% of total (LR FM, 2017b)

The analysis of the Ministry of Finance data shows that in the period from 2011 to 2015, EU funds contribution to real GDP growth averaged about 1.3 percentage points (LR FM, 2017a). According to the report published in October 2016 (LR FM, 2017b), 26\% of all funds received from the concluded contracts for financing projects are related to the transport industry (Fig. 3).

Information on the Ministry's total planned expenditure, the planned number of posts in the period from 2017 to 2019 is reflected in the "On State Budget 2017" Law, in the explanations' 17th chapter "Ministry of Transport" (Satiksmes ministrija, 2017). The division of planned investments by areas is presented in Table 2 .

Table 2. The procedure of investments' allocating, EUR (Satiksmes ministrija, 2017)

\begin{tabular}{|l|r|r|}
\hline Investments & 2018 plan & 2019 plan \\
\hline 1. Policy planning & 5444314 & 207906964 \\
\hline 2. Roads & 209057944 & 40850570 \\
\hline 3. Railroad & 26169830 & 82418 \\
\hline 4. Aviation & 82418 & 158449 \\
\hline 5. Transit & 199819 & 85449544 \\
\hline 6. Passenger transport & 85803362 & 2229881 \\
\hline 7. Communications & 2229881 & \\
\hline
\end{tabular}

A public-private partnership is a promising mechanism for attracting non-state funds and it is one of the main tools of investment policy in the development of transport infrastructure worldwide. Within the framework of such joint work, issues related to the distribution of risks, the level of obligations and the duration of project implementation are identified. The data presented in Figure 3 indicate a reduction in investment from the European funds and this will lead to the necessity for a cooperation agreement with the private sector. The role of private sector investment (public-private partnership) is shown as findings taking from case studies of successful private sector involvement in transport infrastructure financing in the leading countries, for example, in Germany (Kuzmina-Merlino et al., 2018).

With the increasing role of the venture capital in the Latvian economy, the use of private funds for financing transport projects is not sufficiently disseminated for various reasons; such capital investment projects require a certain time for their payback and do not make easy profits for investors. The role of the government, state institutions and local governments significantly increases under such circumstances.

\section{Example of Successful Investment Project}

In Latvia the experience of the State Joint-Stock Company "Latvijas dzelzcelıš" (SJSC LDZ) is of interest for analysing successful investment projects. The financial year of the SJSC LDZ ended with 
positive results contrary to cautious forecasts at the beginning of 2015 (Skorobogatova and KuzminaMerlino, 2017). High-quality railway infrastructure is significant for economic development, as it allows traders to transport goods by rail, and it generates income for the State both by means of direct income and by taxes and the economy as a whole, as well as, of course, contributes to many dozens of thousands of jobs. High-quality rail infrastructure provides passengers with convenient and quick access to the chosen destination. Investments in infrastructure facilitate a contribution to the national economy according to the estimate of world experts; a 10\% increase in investments in transport infrastructure gives about $1 \%$ growth in GDP.

The year 2015 was the year with the focus on investment projects for the SISC LDZ - the largest amount of investments in company history ever, has been up taken during this year. The last year of the previous EU financial programming period was the rationale as to why all investment projects with EU co-financing launched during the previous five years had to be completed.

\section{1) Modernization of the railway passenger infrastructure}

SJSC LDZ completed the project at the end of 2015 aiming to improve the quality and efficiency of the railway passenger service within Riga and the suburban area by integrated modernization of the public railway infrastructure at 16 stations, ensuring the sustainability of the railway operations in the public transport system of Riga City and the suburban area while reducing environmental pollution. Total expenditure: EUR 17,59 million.

\section{2) Replacement of railway switches - delivery of switches}

The project aims to ensure and enhance the carrying capability of the railway tracks on the "Rail Baltica" East - West corridors. Timely replacement of rails and essential components - switches, the operation and durability of which determine the safety and speed of train traffic, is of vital importance for the infrastructure of such significant workloads like they are in the Latvian railway, with intensive traffic of heavy and long trains. Attraction of European Union funds enabled SJSC LDZ to significantly reduce the maintenance costs of switches. Total expenditure: EUR 16, 2 million.

SJSC LDZ has been assigned another six projects to be carried out within a fairly tight schedule in 2015, among which were - Bolderaja 2 Station with Railway Tracks Linking It to Terminals at Krievu Island, Upgrade of Liepaja Station Signalling System Along with Reconstruction of the Railway Track, as well as construction of the Second Railway Track at Skriveri-Krustpils Connection and others (LDZ, 2016).

\section{Enhancement of Development Performance of Transport Infrastructure by Ameliorating Investment Policies}

The main source of financing the transport sector in Latvia is EU funds. According to the Ministry of Transport of the Republic of Latvia investments in the transportation sector (years 2004-2006 and 2007-2013) amounted in total of EUR 2012,54 million, including financing of EUR 1459,35 million from the EU funds; of EUR 32,77 million from Trans-European Transport Network (TEN-T); and state, municipalities and private funds together provided EUR 520,42 million. For the period 2014-2020 it is planned to draw funds from the European sources in the amount of EUR 1,3 billion for the purposes of maintaining and developing the transport infrastructure (Ministry of Transport of Latvia, 2016).

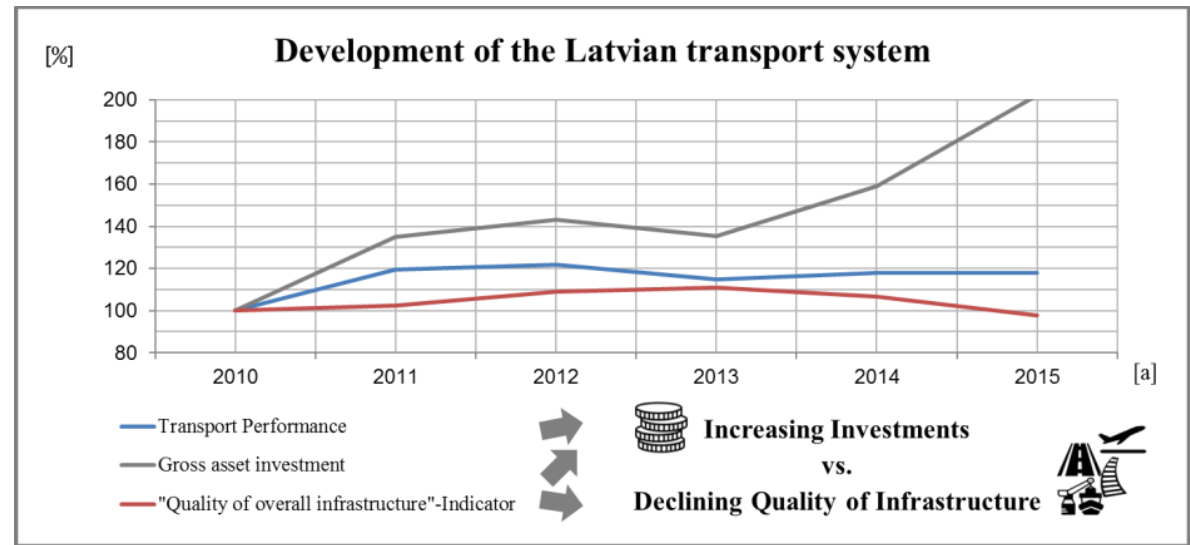

Figure 4. Development of the Latvian transport system (Kuzmina-Merlino et al., 2018) 
The OECD data shows that in 2015 total investment in infrastructure development increased more than 12.5 times comparing with 2000 (see Fig. 4). In Latvia, the priority in transporting goods is given to roads and the railway. It is interesting to see the distribution of investment between these decisions. If in 2000 , only $25 \%$ of the total amount of allocated investment was on roads, then in 2015 the allocated EUR 412 million is divided almost equally. At the same time, it should be noted that despite the positive dynamics of investments, the indicator "Quality of overall infrastructure" in 2015 was only 4.4. This is the lowest index for the last 6 years.

Analysis of the statistical data leads to conclude that there is a need to develop a conceptual approach for the selection of investment projects and making an effective investment decision.

Figure 5 shows a concept intending to support the decision making regarding investments in transport infrastructure in Latvia. On the one hand, the cost-benefit-analysis as the standard method for ex-ante assessments of infrastructure projects is used. The assessment is based on the cost-benefit ratio, which shows all effects in monetary units and compares it with the investment costs. The practical determination of values is aggregated on the on hand by benefit sub-indicators (indicators such as declining transport time, increasing traffic safety, maintenance of traffic routes) and, on the other hand, by cost sub-indicators (indicators such as route, vehicle or material costs) and then summarized in an overall indicator.

Since the cost-benefit analysis alone is not sufficient to assess the impact of infrastructure concepts, it should be supplemented by a multi-criteria analysis. This analysis considers relevant but "missing" effects in a transparent and efficient way in the decision-making process (Barfod et al., 2011; Leleur et al., 2007)

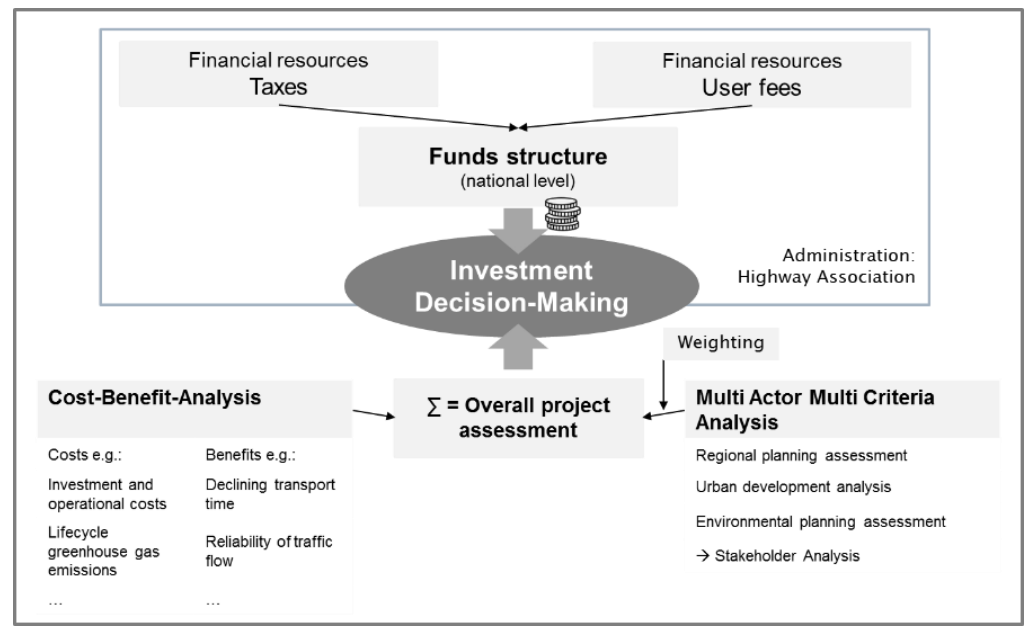

Figure 5. Investment Decision-Making Concept (Kuzmina-Merlino et al., 2018)

The composite modelling assessment (COSIMA) takes into account impact types such as regional, urban and environmental development, network accessibility or driver convenience, which have to be measured in appropriate types of quantitative units (e.g. regional development: the number of newly created jobs; network accessibility: gain in contact hours for specific trip types) (Leleur et al., 2007). Some effects cannot be measured quantitatively, which is why an additional multi-actor analysis is used to include different stakeholder's points of view (Macharis and Bernardini, 2015).

The Analytical Hierarchy Process (AHP) makes it possible to determine a score for each alternative by setting up a target hierarchy, determining the priorities of individual elements, calculating weighting factors, performing a consistency check and finally compiling an overall hierarchy (Saaty, 2008). The results from AHP scores and all quantifiable units are then translated through weighting factors (e.g. determined by simple multi attribute rating techniques such as SMARTER (Goodwin and Wright, 2009)) into an overall project assessment, which sum indicates the assumed total benefit of the individual planning variants.

This process is opposed by the fund structure at the national level combing both money from the public and private sectors. In the case of Germany, the focus is on reliable and adequate financing through traffic-specific taxes and fees as well the expansion of the earmarked user financing (Daehre, 2012; Schmidtke and Behrendt, 2017). At this level, the Investment Decision-Making Concept managed by the 
administration of Highway Association (Fig. 5) can be recommended for Latvia as a possible approach for the evaluation of investment projects.

\section{Conclusions}

1. The better the transport infrastructure is developed, the greater the competition and freedom of economic activity, the greater the opportunities for enhancing the conditions and living standards of the population in any country or region. The objectives of transport infrastructure development are considered in the context of strategy of the country's sustainable development; the Latvian government documents declare transport industry as a priority in the development of the Latvian economy.

2. Investments into transport infrastructure are attractive for investors, which are proved by the increase in investment funds into the transport sector. However, there is still a significant gap between the real needs of the sector and available financing funds.

3. The analysis of the accessible statistical information has revealed that Latvia makes use of different sources of funding: government and European funds and private funding to a lesser extent, though. The role of the state in funding the transport sector remains the leading one, yet, it is obvious that the state cannot withstand the increasing requirements for financing this sector.

4. To secure the longitudinal sustainable development of transport infrastructure, it is important to develop a mechanism for making investment decisions, which could be based on the concept of Investment Decision Making, developed by the authors and aimed at policy-makers, professionals, academics, and those with a broad interest in the field. According to the authors, the development of qualitative investment projects, more careful selection of projects, development of the system of performance measurement and efficiency assessment are essential for providing fruitful and effective financing.

\section{Acknowledgements}

This paper is based on the research and work that has been conducted in the framework of the ALLIANCE project (http://alliance-project.eu/), which has received funding from the European Union's Horizon 2020 Research and Innovation Programme. The authors would like to thank both the consortium of the project and the European Commission.

\section{References}

1. Barfod, M.B., Salling K.B., Leleur, S. (2011) Composite decision support by combining cost-benefit and multi-criteria decision analysis, Decision Support Systems, Volume 51, Issue 1, pp.167-175.

2. Daehre K.-H., (2012) Zukunft der Verkehrsinfrastrukturfinanzierung. Final Report, Federal and State Commission, Magdeburg, p. 37.

3. Goodwin, P., Wright, G. (2009) Decision Analysis for Management Judgments, 4 Editions, Wiley, p. 468.

4. Investment and Development Agency of Latvia, LIAA (2015) Business Infrastructure, Available from: http://www.liaa.gov.lv/en/invest-latvia/investor-business-guide/business-infrastructure

5. Investment and Development Agency of Latvia, LIAA (2016) Transit and Logistics, Available from: http:/www.liaa.gov.lv/en/trade/industry-profiles/transit-and-logistics

6. Investment and Development Agency of Latvia, LIAA (2018) Transport and Storage, Available from: http://www.liaa.gov.lv/node/626

7. Ferrari, C., Bottasso, A., Conti, M., Tei, A. (2018) Economic Role of Transport Infrastructure: Theory and Models. Elsevier.

8. Kuzmina-Merlino, I., O.Skorobogatova, N. Schmidtke, F.Behrendt (2018) Mechanism for Investment in the Transport Infrastructure Development in Latvia, The Proceedings of the $17^{\text {th }}$ International Multidisciplinary Conference on Reliability and Statistics in Transportation and Communication (RelStat-2017) in: Lecture Notes in Networks and Systems, Volume 36, Springer, pp. 507-518.

9. LDZ (2015) Latvijas dzelzceľ̦s Annual report 2015, Available from: https://www.ldz.lv/en/annualreports 
10. Leleur, S., Petersen, N.B., Barfod, M.B. (2007) The COSIMA Approach to Transport Decision Makung: Combining Cost-benefit and Multi-criteria Analysis for Comprehensive Project Appraisal, Korean Development Institute \& World Bank Conference, Seoul, pp. 2-5.

11. LR FM (2017a) Latvijas Republikas Finanšu ministrija, ES fondu ieguldījums pa regioniem un nozarēm. Available from: http://www.esfondi.lv/es-fondu-investiciju-progress-latvijas-regionos-unpasvaldibas

12. LR FM (2017b) Latvijas Republikas Finanšu ministrija, Rezultāti, Available from: http://www.esfondi.lv/es-fondu-uzraudzibas-raditaju-progress

13. Macharis, C.; Bernardini, A. (2015) Reviewing the use of Multi-Criteria Decision Analysis for the evaluation of transport projects, Time for a multi-actor approach, Transport Policy, Volume 37, pp.177-186.

14. Ministry of Transport of Latvia (2016) Izaicinājumi publiskās autocel̦u un dzelzcel̦a infrastruktūras finansēšanā - regulējums, resursu piesaiste, iespējamie finansēšanas modeḷi. Available from: http://www.sam.gov.lv/images/modules/items/PDF/item_6440_Dins_Merirands_20.10.2016.pdf

15. Nadiri, Ish. and Banani, N. (1997) The Changing Structure of Cost and Demand for the U.S. Telecommunications Industry, Information Economics and Policy, vol. 9(4), pp. 319-347.

16. Oxford Economics (2015) Assessing the global transport infrastructure market: Outlook to 2025, Available from: www.pwc.com/outlook2025

17. Panayiotou, A., Medda, F.R. (2014) Attracting Private Sector Participation in Transport Investment. Procedia-Social Behavioural Sciences, volume 111, pp. 424-431.

18. Rodrigue, J.-P., Comtois, C., Slack, B. (2017) The Geography of Transport System, New York: Routledge.

19. Saaty, T.L. (2008) Decision making with the analytical hierarchy process. Int. J. Services, University of Pittsburgh, Vol.1, No.1, pp. 83-98

20. Saeima of the Republic of Latvia (2010) Sustainable Development Strategy of Latvia until 203, Available from: https://www.cbs.nl/NR/rdonlyres/B7A5865F-0D1B-42AE-A838-FBA4CA31674D/0/Latvia_2010.pdf

21. Satiksmes ministrija (2017) Activity Strategy 2017.-2019.gadam, Available from: http://www.sam.gov.lv/images/modules/items/PDF/item_6713_SM_IDS_2017-19_07_03_2017.pdf

22. Skorobogatova, O., Kuzmina-Merlino, I. (2017) Transport Infrastructure Development Performance, 6th Conference on Reliability and Statistics in Transportation and Communication, RelStat'2016, 19-22 October, 2016, Riga, Latvia, Volume 178, pp. 319-329.

23. Schmidtke, N. and Behrendt, F. (2017) Impact analysis of freight transport scenarios on the German transport system - an indicator based approach, In: MultiScience - XXXI. microCAD International Multidisplinary Scientific Conference, 20-21 April, 2017, University of Miskolc, Miskolc, Hungary

24. The Global Innovation Index (2017) Analysis. Available from: https://www.globalinnovationindex.org/analysis-indicator/

25. The World Bank (2018) Doing Business Available from: http://www.doingbusiness.org/about-us

26. Zhan, J. (2015) Investment, Infrastructure and Financing the Sustainable Development Goals, WTO. Workshop on Aid for Trade and Infrastructure: Financing the Gap. Available from: http://unctad.org/Sections/dite_dir/docs/diae_stat_2015-02-16_WTO-aid-for-Trade_en.pdf 